\title{
"In Fact, We Can All Decide": An Action Research on the Participation Right of Young Children
}

\author{
Tuğçe Akyola
}

$\begin{array}{ll}\text { Received } & : \text { 27 October } 2020 \\ \text { Revised } & : 16 \text { March } 2021 \\ \text { Accepted } & : 2 \text { April } 2021 \\ \text { DOI } & : 10.26822 / \text { iejee.2021.209 }\end{array}$

'Tuğçe Akyol, Faculty of Education, Early Childhood Education Department, Afyon Kocatepe University, Afyonkarahisar, Turkey

E-mail: akyol.tugce@gmail.com

ORCID: https://orcid.org/0000-0002-5860-9236

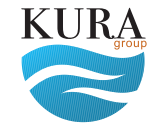

Copyright @

www.iejee.com

ISSN: 1307-9298

(c) 2021 Published by KURA Education \& Publishing. This is an open access article under the CC BYNC- ND license. (https://creativecommons.org/ licenses/by/4.0/)

\begin{abstract}
In this research, it is aimed to plan concrete and new arrangements that will encourage participation right and evaluate how these arrangements contribute to children's participation. The participants of the study are comprised of 415 -year-old children attending the kindergarten in a province in Turkey's inner Aegean region. In the research, triangulation was used, and Participation Right Scale in Preschool Classes (Koran, 2017; Şallı Idare, 2018), interview form (Thayer and Schiff (1969), facial expressions form, observation form, and field notes were used as data collection tools. When the results from the scale, observations, and interviews were evaluated, it was determined that children began to express their views on the planning of programme activities and began taking an active role in decision making. Furthermore, it was concluded that children began to be active participants in the learning process and liked the arrangements and the materials they used in the classroom. This action research, focusing on the children's participation right, is thought to contribute to academic and social studies on how the participation right in school can be transferred from theory to practice. Comprehensive action plans can be developed by experts working on children and education policy makers in order to implement children's participation right in school.
\end{abstract}

\section{Keywords: \\ Action Research, Participation, Participation Right, Young Children.}

\section{Introduction}

It is highlighted that child participation is one of the critical issues in early childhood education (Clark \& Moss, 2010; Venninen \& Leinonen, 2013). According to the United Nations Committee on the Rights of the Child (2009) participation is sharing information and listening to children. After the first step of participation, including information sharing and listening, children's decision making abilities regarding their daily lives are considered as active participation (Alderson, 2008; Shier, 2001). Article 12 of the United Nations Convention on the Rights of the Child (1989) impresses children's opinions on situations where their concerns 


\section{iejee $\approx$}

should be taken into account. The implementation of this item is remarked as a "practice of participation" (United Nations Committee on the Rights of the Children, 2009). Children need to practice decisionmaking to be active decision-makers (Hart, 1992). The right to participate includes the freedom of children to express themselves with or without language, the freedom of thought, the right to information, the right to take their views in their daily lives (Nyland, 2009). For this purpose, it entails understanding that all children have the capacity to express their opinions, providing environments where they can express their opinions easily, being aware of the situations that concern them, and respecting their opinions according to their age and maturity (Landsdown, 2005).

Although participation right is emphasized in early childhood policies and programs, it is still limited in practice (Bae, 2009; Theobald et al., 2011). Child participation requires children as active and democratic citizens to have a voice in areas that affect their lives, such as education (Horgan, 2017). Hammersley (2017) states that adults should not have an authoritarian view of children to be taken into account for the views of young children. Providing children with the opportunity to express their views on issues related to them depends on their perspective on their competencies. Perceiving children as active and capable members of society guides their participation (Hester \& Moore, 2018). Participation is about children's self-regulation and individual freedom, and interaction between adults and children and adults' control over children's school life affect this process (Puroila et al., 2012).

The teacher has an essential role both as an observer and a supporter of their skills development to encourage children's participation (Berthelsen, 2009). The participation of young children in school differs depending on the teacher's communication, attitude, rules, and power (Emilson \& Johansson, 2018; Johansson et al., 2016). Teachers can encourage participatory practices at different levels from three different perspectives; including being open to the idea of participation, creating opportunities for participatory experiences, and realizing these new participatory experiences in daily practice (Shier, 2001). In order to ensure participatory processes by considering the needs of children, it is necessary to take into account children's opinions (Muela et al., 2019). A little guidance for teachers to make them understand children's opinions and integrate them will be sufficient (Sargeant \& Gillett-Swan, 2019). Failure to consider children's opinions stems from reasons such as teachers' perspectives on children, insufficient support for teachers to improve classroom participation, excessive classroom capacity, and the number of children quota per teacher (Smaree-Manassakis, 2019). Children are not provided with environments where they can start the process spontaneously or direct them in schools (Theobald \& Kultti, 2012). The fact that teachers are regarded as the organizers of the classroom environment, who has the responsibility to provide space for children, causes children to be perceived as only users rather than participants. (Donaldson, 2015; Taylor et al., 2015). Based on all these factors, it is required to support child participation and design new educational approaches and practices that value children's opinions as a member of the group (Venninen, Leinonen, Lipponen, \& Ojala, 2014). This study will discuss the new arrangements planned to support classroom participation.

It is essential to approach child participation in early childhood from a theoretical perspective, from a convenient viewpoint, for children to be involved in decision-making processes (Church \& Bateman, 2019). Teachers have difficulties in taking children's opinions into account in the classroom. This is due to the challenges that children have encountered in using appropriate methods such as visual methods and supporting their participation in discussions that affect their experiences in school (Kanyal \& Cooper, 2012). In the busy and structured daily schedule, there is not enough time for teachers to listen to children or the opportunity for children to express their opinions. Therefore, it is essential to change daily routines, schedules, and review general goals to encourage child participation (Ojala \& Venninen, 2011). Providing enough time for children to listen individually or in a group, establishing routines for children's interests and needs, discussing classroom rules and making decisions together, and getting children's opinions about solving problems to include suggested ways to support participation (Clark, McQuail, \& Moss, 2003). By creating learning environments with democratic and participatory features, the political and social importance of participation will be highlighted (Clement, 2019). It is emphasized that child participation should be supported by designing and creating learning environments (Clark, 2010; Correia \& Aguiar, 2017). It is important to organize daily routines by taking children's opinions into account to create a participatory environment in the classroom and build participation culture (Joseph et al., 2010).

It is emphasized that novel participatory methods and practices can be developed to encourage child participation (Clark \& Moss, 2010; Venninen et al., 2012). Previous studies examined participatory experiences in the classroom (Clement, 2019; Houen et al., 2016; Leinonen \& Venninen, 2012; Smaree-Manassakis, 2019). A study by Johansson et al., (2016) found that children were given the opportunity to express themselves in the classroom, but teachers rarely took children's opinions into account. The results revealed that children's opinions are taken into account only when they are consistent with adults' previous plans and 
expectations. In a study of Leinonen and Venninen (2012) examining the participation of young children in planning their learning processes at school, it was observed that children did not participate sufficiently in planning, and evaluation was insufficient. Instead of limiting children's participation in decision-making process in learning environments, it is necessary to ensure that they also become an active determinant of the learning process (Church \& Bateman, 2019). While considering all these, this study aimed to plan concrete and new arrangements that will encourage child participation and evaluate how these arrangements contribute to children's decisions about the daily schedule, learning environment, and their emotional responses to materials and arrangements. This study will be critical to reveal how theoretical ideas on child participation will affect the implementation and an action plan that will encourage child participation in enriching the future studies on child participation in classroom.

\section{Method}

\section{Research Design}

The study conducted an action research, one of the qualitative research methods. Action research is an analysis process that is conducted to determine and improve the quality of teaching and methods applied in the school or classroom environment (Johnson, 2015). According to Yıldırım and Şimşek (2016), action research is a study that is conducted by a practitioner alone or with a researcher, and includes systematic data collection and analysis that aims to reveal and solve problems that may arise during the implementation process. In this study, participatory action research was conducted, in which the practitioner was also a researcher. Participatory action research is described as an approach that involves a social analysis with a dynamic process based on social and collaborative (Gillis \& Jackson, 2002; Hendricks, 2006). Action research involves a cyclical process providing change with participatory methods (Smith, 2015). This research was conducted in four stages: choosing to change, planning for change, observing, reflecting, and acting and revising plan (MacNaughton \& Hughes, 2009).

The researcher examined child participation, teacher's opinions on child participation, and research on developing children's participation in the classroom (Koran \& Avcl, 2017; Salminen, 2013; SmareeManassakis, 2019). When she considered the studies in the literature, and during her field studies, the limited participation of children in decision-making regarding classroom activities and learning environments drew the researcher's attention. The researcher estimated that more concrete and applicable processes were required to encourage child participation. Based on all of these factors, it was focused on that the participation could develop positively with the new arrangements and materials to be prepared in the classroom.

In order to determine the participation and decisionmaking of children in the class, observations were made by the researcher, who will carry out the application third days a week in classrooms for two weeks and interviews were conducted with the classroom teachers. As a result, it has been observed that children are limited in their daily schedule in decision-making about classroom activities and learning environments. It was also observed that children's participation is insufficient. In order to resolve this problem and to put the change into practice, visual materials that can be used in the daily schedule of The Preschool Education Program of the Ministry of National Education (MoNE) (2013) were prepared. The arrangements for the use of these materials were planned and were carried out four days a week in classrooms for six weeks. In the third phase of the action research, all of these materials were used in the classroom for six weeks as part of the regulations in the classroom.

\section{Participants and Settings}

Criterion sampling, one of the purposeful sampling methods, was used in this study. The criteria for determining the classes in which the research can be conducted involve insufficient participation of children in classrooms none practice enhancing child participation, and preschool teachers being interested and volunteering to work. These activities planned by the researcher were performed in a kindergarten in a district center of Turkey's inner Aegean region, under the Directorate of National Education, where children with middle socioeconomic background attend. The arrangements were carried out in two classrooms for five-year-old children. There are music, science, art, and dramatic play centers in both classrooms, and there are materials suitable for children's developmental levels. Also, there is a playground for children outside the kindergarten.

One of the teachers in the applied classes has 12 years, and the other has four years of professional experience. Both teachers are female and graduate of the Preschool Education Undergraduate Program. None of the teachers took an undergraduate course on child participation and did not participate in any in-service training. In the study group, there are a total of 5-year-old 41 children, 21 boys, and 20 girls.

\section{Procedure}

Data collection was first conducted voluntarily by obtaining permission from the Directorate of National Education and consent forms from the families of the children in the study group. In this action research, 
Table 1:

Action Research Process

\begin{tabular}{|c|c|c|}
\hline Stage & Week & The content \\
\hline \multirow{4}{*}{ Stage 1} & 1 & Literature Review \\
\hline & 2 & Literature Review \\
\hline & 3 & Obtaining all required permits \\
\hline & 4 & Meeting with the teacher and getting approval \\
\hline \multirow{4}{*}{ Stage 2} & 5 & Observing children's participation and the classroom \\
\hline & 6 & Observing children's participation and classroom \\
\hline & 7 & Pre-test-Interviews \\
\hline & 8 & Pre-test-Interviews \\
\hline \multirow{6}{*}{ Stage 3} & 9 & Classroom arrangements-observation-interview-field notes-photos \\
\hline & 10 & Classroom arrangements \\
\hline & 11 & Classroom arrangements \\
\hline & 12 & Classroom arrangements \\
\hline & 13 & Classroom arrangements \\
\hline & 14 & Classroom arrangements \\
\hline \multirow{2}{*}{ Stage 4} & 15 & Post-test-Interviews \\
\hline & 16 & Post-test-Interviews \\
\hline
\end{tabular}

Table 2

Materials Used in the Research

\begin{tabular}{|c|c|}
\hline Material Name & How to use it \\
\hline Rabbit Bondi & $\begin{array}{l}\text { When starting the day, children place a card with the day written on it in the rabbit's pocket. Every } \\
\text { day one of the children places a symbol/picture/text symbolizing a pre-determined conversation } \\
\text { topic into the rabbit's pocket and starts the conversation. Children sit in a circle and share their ex- }\end{array}$ \\
\hline
\end{tabular}

Color Wheel

Children go to the learning center symbolized by the picture, which appears as they spin the wheel and play for a specific time.

The playing time continues until the song of the day, determined by the children ends. When the time is up, children mark the learning centers they played on the board. Children can change the learning center by turning the wheel again, or those who want can continue playing in the center.

Children place picture cards symbolizing activities and routines in the daily schedule on the caterpillar. They can follow the daily training flow from the caterpillar. The teacher can plan two of the activities of that day so that the children can choose, decide, and explain the optional activities to the children with the picture cards in the caterpillar.

Children can participate in any of the optional activities. Besides, when the teacher is talking about the next day's activities at the time of evaluating the day, an activity type decided with the children can be put on the caterpillar.

The teacher may hold voting in the classroom using these colored decision cards for various situations, such as an activity selection/a field trip to be planned, etc./a material to be purchased for the classroom. For example, voting can be applied to decide on one of the two songs determined together with the children for the music during the game activity.

Decision cards

There are cubes with pictures of different actions, spoons, hand, and finger puppets belonging to different characters and dice in the chest. If they want, children can sit in a circle and tell stories/rivStory Chest eting events/dreams they have, using cubes and puppets during the time to "start the day/time to evaluate the day" period. Children can change pictures and puppets on the cubes at certain times.

more than one data collection method triangulation was used, and the data collection was conducted systematically.

As discussed in the literature, different data collection methods can be applied to comprehensively conduct action research and support the findings (Johnson,
2015). Participation Right Scale in Preschool Classes, interview forms, facial expressions form, observation forms and field notes were used as data collection tools in this study.

Participation Right Scale in Preschool Classes: This scale was developed by Koran (2017) TRNC (Turkish Republic 
of Northern Cyprus) to determine child participation in preschool education institutions. The reliability coefficient of the scale was found to be .85. (Koran, 2017). The validity and reliability study of the scale in Turkey was conducted by Şallı-idare (2018). The results of the confirmatory factor analyses performed for the validity and reliability of the teacher and child form of the scale in Turkey, revealed that the factor loadings of the items were greater than .32 for all dimensions, and the four-factor structure was acceptable. The scale includes teacher and child forms, and both forms contain the same questions. The child form was used in the study. The scale consists of 23 items with two dimensions and seven sub-dimensions. The daily schedule dimension has the following three subdimensions: activities, playing and sharing activities in learning centers/outdoors. The determining classroom rules and procedures dimension have the following four sub-dimensions: going out of the classroom, expressing opinion in the classroom, consuming food and beverage in the classroom, and operations (Şallıidare, 2018).

The scale items are scored with 2 points as participation is fully took place in the decisions taken by children and adults, 1 point for the decisions made by the children only, and 0 points for an option that does not involve the children. In this study, all application steps determined by Koran (2017) were followed while implementing the scale. Before starting the application, a game was played together to make the child feel more comfortable, and permission was requested from the child for recording. During the application, the researcher and child sat face-to-face at the table, and the scale was introduced to the child at first. While reading the practitioner-scale questions, the child used a seal on the blank fields to mark the scale (Şallı-idare, 2018). The scale was administered to the children twice, before and after the action plans were applied.

Observation form. In the second stage of this research, the researcher observed the classrooms for two weeks and recorded observations on the form to determine the children's participation, to know the classroom thoroughly, and increase the interaction with the children. During the third phase of the action plans, the researcher observed the children's participation and decision-making processes and the classroom environment for six weeks.

Interview form. In the first stage of this research, conversation-style interviews with predetermined questions were conducted with the teachers to get to know the classroom to be applied. In the second stage, focus group interviews were conducted with the children to determine child participation. Through the implementation, focus group interview, with children were held. Developed semi-structured interview forms were presented to three field experts' opinions to ensure internal validity. The required corrections were made under the views of the field experts, and the form was finalized. Interview form consists of five open-ended questions. The teachers were asked questions such as whether they decide together with the children in their daily schedule, and what they decide. In the interview form prepared for children, there are questions like, "What did you decide by using the materials in the classroom? Did you enjoy using the materials in the classroom?"

Field notes. The researcher took field notes for evaluations through the application. The field notes include children's reactions, perceptions, and differences in the arrangements performed in the classroom

Facial Expressions Form. Facial expressions form, developed by Thayer and Schiff (1969), consists of visuals containing 11 facial expressions. Facial expressions show emotional states and include the presentation of confused, serious, happy, sad, angry emotional states in several ways. At the end of each application, the children were asked to find and mark the facial expression according to their feelings.

\section{Data Analysis}

The study uses two different research methods, qualitative and quantitative, to achieve its objective. Normality tests were implemented in order to analyze the quantitative data. As a result of the normality test (Shapiro-Wilk test) of the scores obtained from the scale applied in the study, the Wilcoxon signed-ranks test was performed for comparisons within groups as the values were not normally distributed. The significant level of .05 was set as the threshold, and it was stated that there was a statistically significant difference when $p<.05$ and that there was no statistically significant difference when $p>$.05. (Büyüköztürk, KılıçÇakmak, Akgün, Karadeniz, \& Demirel, 2012).

The descriptive analysis technique was used to analyze the qualitative data obtained from the observations, interviews, and field notes. In the descriptive analysis, the data are interpreted according to predetermined themes. In the first stage of the descriptive analysis, a framework is created. In the second stage, the data are processed under the framework. The findings are defined in the third stage, and while findings are interpreted in the last stage (Yıldırım \& Şimşek, 2016). In this study, a diagram was constructed by determining the themes based on the research questions, and the observation results were evaluated before the application. In the second stage, an action plan was developed. The data obtained from the observations, interviews, and field notes formed during and after the implementations were analyzed according to 


\section{iejee $\approx$}

themes. In the last stage, the findings concerning the themes were revealed and interpreted by making direct quotations.

\section{Validity and Reliability of the Research}

It is required to ensure validity, reliability, and variation in action research (Johnson, 2015). The researcher made long-term participation and observations in the practice environment to increase the internal validity of the research (Lincoln \& Guba, 1985.) The implementation steps, data collection, and participants are explained in detail to increase credibility. Besides, data triangulation was done using multiple data collection tools. The whole research process was described in detail (Lincoln \& Guba, 1985) and direct quotations were made in presenting the findings to increase the external validity and transferability of the research (Yıldırım \& Şimşek, 2016). Due to ethical concerns, the names of the participants were not used and thus the children were coded as C1, C2, C3, $\mathrm{C} 4$, etc. To ensure the reliability of the research, results, and interpretations, raw data were presented to an independent expert. For the reliability of the study, the examination and coding of the interview texts were followed by two independent researchers, and the analysis of the data was performed by the researchers separately. In order to calculate inter-coder reliability, the reliability formula Miles and Huberman (1994) was used, and the reliability between coders was calculated as .84 .

\section{Results}

The findings of the research will be presented under the following three themes: the decisions made by the children about the daily schedule, and the learning environment, their emotional reactions to the materials, and arrangements.

\section{Children's Decisions about Daily Schedule}

Pre-test and Post-test Results of the Scale for Participation Right Scale in Preschool Classes

The findings of the pretest and posttest mean scores revealed that the posttest mean scores are significantly higher $(p<.05)$ than the pretest scores (Table 3). Accordingly, it would be safe to say that the action plan is effective in increasing the right of children to participate in the classroom.

\section{Results of Pre-interview and Post-interview}

The results of the interviews with the children before the action plan was performed revealed that 31 of 41 children made the classroom decisions by the teachers, nine by the principal, and one by their parents. After the implementation, 34 children reported that teachers and children make decisions; three reported that only children make decisions, two children stated that the principal makes the decision, one child reported that his friend makes the decision, while one child reported that only the teacher makes decisions. While children' statement revealed that the classroom decisions were made by the "teacher" before the arrangements, 08 reported that "We can make decisions too. In fact, we can all decide." after the arrangements. While the children emphasized that the teacher makes the decisions by saying, "Always the teacher, but sometimes we ask to go to the park." in the C17 pre-interviews, he said, "The teacher and we decide." in the post-interviews. In the pre-interview, C1 said, "I do not decide with the teacher, my teacher decides." in the post-interview, C1 said, "We decide some activities together." C11 stated that they decided to "drink water," with his teacher before the arrangements, "play toys, read stories, tell fairy tales about butterflies" after the arrangements.

Table 3.

Pretest and Posttest Results of the Scale

\begin{tabular}{|c|c|c|c|c|c|c|c|c|}
\hline & & & & & & & \multicolumn{2}{|c|}{ Wilcoxen signed rank test } \\
\hline Sub-dimensions & $N$ & Mean & Median & Min. & Max. & $S D$ & z & $p$ \\
\hline Activities sub-dimension pretest & 41 & 1,12 & 1,00 & 0,00 & 3,00 &, 90 & \multirow{2}{*}{$-5,60$} & \multirow{2}{*}{.0001} \\
\hline Activities sub-dimension posttest & 41 & 9,39 & 9,00 & 3,00 & 13,00 & 1,74 & & \\
\hline Play sub-dimension pretest & 41 &, 56 & 0,00 & 0,00 & 2,00 & ,63 & \multirow{2}{*}{$-5,63$} & \multirow{2}{*}{.0001} \\
\hline Play sub-dimension posttest & 41 & 3,90 & 4,00 & 2,00 & 6,00 & 83 & & \\
\hline Sharing sub-dimension pretest & 41 & 27 & 0,00 & 0,00 & 2,00 &, 59 & \multirow{2}{*}{5,56} & \multirow{2}{*}{.0001} \\
\hline Sharing sub-dimension posttest & 41 & 3,41 & 3,00 & 1,00 & 6,00 & 1,36 & & \\
\hline Daily Schedule dimension pretest & 41 & 1,95 & 2,00 & 0,00 & 5,00 & 1,36 & \multirow{2}{*}{$-5,58$} & \multirow{2}{*}{.0001} \\
\hline Daily Schedule dimension posttest & 41 & 16,71 & 17,00 & 11,00 & 22,00 & 2,60 & & \\
\hline Classroom Rules sub-dimension pretest & 41 & - & - & - & 2 & 1 & \multirow{2}{*}{$-5,60$} & \multirow{2}{*}{.0001} \\
\hline Classroom Rules sub-dimension posttest & 41 & 5,10 & 5,00 & 3,00 & 8,00 & 1,45 & & \\
\hline Total pretest & 41 & 2,44 & 2,00 & 0,00 & 6,00 & 1,61 & \multirow{2}{*}{$-5,58$} & \multirow{2}{*}{.0001} \\
\hline Total posttest & 41 & 21,80 & 22,00 & 16,00 & 29,00 & 2,91 & & \\
\hline
\end{tabular}


The results obtained from the interviews revealed that the classroom decision making changed positively after the applications.

\section{Results of Observation Forms}

According to the findings gathered from the observation forms, it was found that the decisionmaking in classrooms improved over time and that children were involved in decision-making about activities.

The following was reported regarding the observation form's decision-making processes while the researcher performed the applications: "One of the children said, 'Teacher, we can tell stories next week with music.' We got other children's opinions, and the next week it was decided that the children would tell stories accompanied by music" (Third week).

"Decision cards were presented for the bouncing game and art activity; the children chose the game, and we played the game they decided on." (Fourth week).

"Children can say that they have decided on some questions asked during the day. They learned what it means to decide." (Eighth week).

The findings of the observation forms revealed that the decision-making in classrooms has improved over time, and children were involved in decision-making process about activities.

\section{Children's Decisions about the Learning Environment}

\section{Results of Pre-interview and Post-interview}

In the pre-interviews with the children, 12 of the 41 children stated that they did not make a decision about the learning environment, 14 of them stated that their teachers made their decision, 9 of them stated that they decided on play and toys, 5 of them decided to go outside, and 2 of them did not answer the question. In the post interviews, 30 children responded with stories and games, 8 with children's learning centers, and 2 with toys. C4 said that "I have never tried, I don't know," about the decisions she made in the learning environment in the pre-interviews, and in the last interviews, she said that "I decide the decision cards, tale, and wheel." C5's statement about the decisions in the learning environment before the applications was as follows: "The teacher makes the decision, not me," and after the applications, he said that "We decided on the wheel and also a story box." C15 said, "I decide which toy to play with" in the pre-interview, and in the post-interview, "I can choose the center and tell stories." The findings of the interviews with the children revealed that children started to make decisions with new materials and arrangements in the learning environment.

\section{Results of Field Notes}

The following was reported about the observation form's decision-making process while the researcher was performing the applications:

"When they took out the puppets and cubes in the fairy tale chest, they got very curious and asked what to do with them. After explaining the materials, I stated that they would make a decision." (First week).

"When I entered the classroom, the children quickly reminded the rabbit, the caterpillar, and the wheel, and together we used the materials accurately." (Second week).

"The children wanted to choose which book they would like to read using their decision cards." (Fourth week).

Based on the field notes, it can be assumed that the children started making decisions using the new materials in the classroom.

\section{Children's Emotional Reactions to Materials and Arrangements}

\section{Results of Face Expressions Form}

The distribution of answers given by the children to the facial expressions form on the application days is presented in Table 4.

\begin{tabular}{lrrrrrr}
\hline $\begin{array}{l}\text { Face } \\
\text { expres- }\end{array}$ & Week & Week & Week & Week & $\begin{array}{r}5 . \\
\text { Week }\end{array}$ & $\begin{array}{r}6 . \\
\text { Week } \\
\text { sion }\end{array}$ \\
\hline Happy & 29 & 30 & 32 & 33 & 34 & 33 \\
Pleased & - & 3 & 1 & - & 2 & 1 \\
Sad & 1 & - & 1 & - & - & 1 \\
Angry & 1 & - & - & 1 & - & - \\
Surprised & 1 & 1 & - & 1 & - & - \\
I don't & 1 & - & 1 & 1 & - & - \\
know & & & & & & \\
\hline
\end{tabular}

The results revealed that children often stated that they were happy with the practices. Stating that they felt happy, C33 and C47 stated the followings:

"I'm happy because I loved the fairy tale chest and the puppets." (C33).

"I'm pleased because the caterpillar was so cute. I like it a lot!" (C47). 


\section{iejee}

\section{Results of Observation Forms}

The examples in the observation form about the emotional reactions of children to materials and arrangements during the applications are presented below:

"The children said they loved puppets so much. They told stories by choosing the puppets they wished." (Second week).

"The children were delighted that we were going to tell a fairy tale. They are very curious and having fun while throwing the cubes." (Fifth week).

"The children liked the decision cards very much, while one of the children chose the cards for the hat, he said, 'Teacher, it is always what I want and they used the decision cards properly." (Sixth week).

When the examples in the observation forms were reviewed, it was found that the children enjoyed using the materials.

The examples in the observation forms proved that the children enjoyed using the materials.

\section{Discussion}

The data obtained from this research, which was conducted to determine the change in child participation as a result of concrete arrangements prepared in line with an action plan to support children's participation, were interpreted in the following three themes: children's decisions about the daily schedule, learning environment, and their emotional responses to materials and arrangements.

It was determined that children's participation was inadequate and they were at a limited level in decision-making about daily schedule, learning environment before to the arrangements to be made in the classroom. It is seen that this result is similar to the results of other studies carried out in this field (Koran, 2017; Salminen, 2013; Zorbay Varol, 2019). Findings of a study examining child participation in early childhood education institutions (Ree \& Emilson, 2019) revealed that when teachers controlled communication, participation was restricted, and passive participation in a supportive communication and joint participation in a collaborative communication were observed. As preschool teachers take children's views into consideration and seek to consider their experiences, they will begin giving children meaningful opportunities for participation (Bae, 2009). Struthers (2015) stated that developing opportunities for children to practice their rights will enable them to learn about their rights.

The results of the scale, observations, and interviews in the theme of decisions about the daily schedule revealed that the decision-making process of children in the classroom improved positively. According to findings, it can be said that with the changes made in the classroom and the use of new materials, children began expressing their views on the planning of program activities. By using decision cards, for example, children began to decide which game to play in class and which book to read. This situation shows that the visual materials prepared in the study are used effectively in making decisions together with children in the daily schedule. The involvement of children in planning programs ensures the implementation of the right to participate (Theobald \& Kultti, 2012). Houen et al. (2016) in the study in which they examined their interactions with children to improve their level of decision-making about their experiences in the classroom, it was concluded that "I wonder..." strategy was effective in children's ability to make choices. It was emphasized by Wall et al. (2019) that one of the processes that take children's views into account in line with the right to participate was to organize appropriate time and space. The teachers should guide children to take action in line with their desires and curiosity so they perform activities based on the right to participate (Church \& Bateman, 2019). In this study, the arrangements that allow children to select the activity they want to participate in, review the daily schedule, and give feedback are considered to have been successful in this positive outcome.

The results of this study on decisions about the learning environment revealed that children started to make more decisions about the learning environment through new materials and arrangements. Children started to act as real participants in the learning environment rather than just being users (Nordtømme, 2012). Smaree Manassakis (2019) indicated that children have the right to organize the materials in the classroom according to the United Nations Convention on the Rights of the Child and reported that young children are aware of their role in organizing their learning environments. Children's ability to share their thoughts about learning experiences with their teachers helps them develop critical thinking skills (Touhill, 2013). Some studies have claimed that the decisions regarding learning environments are made by teachers (Hudson, 2012; Koran \& Avcl, 2017; Şallı-idare, 2018). Children's involvement in decisionmaking process and their active participation in the learning environment may differ depending on the experiences and opportunities provided by the teachers. Clement (2019) examined the impact of a democratic-pedagogical approach that deals with co-designing and organizing the classroom to support young children's participation. He noted that, children, by using this strategy, engaged in in-class activities like problem solvers and architects, and the relationship between teacher and child has changed 
positively, enriching engagement, collaboration, and democracy in the classroom.

Furthermore, looking at the results of the children's emotional reactions to materials and arrangements, it was found that children were mostly satisfied and enjoyed using the materials during the applications. Given that physical arrangements may improve or limit children's participation (Bowden-Clissold, 2013; Leinonen \& Venninen, 2012), it can be considered that active participation of children in the changes affecting the classroom is an important development.

The results of this research showed that concrete and new arrangements that support the participation right in the classroom positively changed child participation. One of the differences that this study contributes to the relevant literature is the results of the action plan, which promotes child participation and how the participation right can be fulfilled in the classroom. This action plan, which is based on the active participation of children in the Preschool Education Program Ministry of National Education in Turkey (MoNE) (2013) gives children the freedom to choose the material to play with, the opportunity to plan and apply, and the emphasis placed on the participation right directly, can contribute to the studies on how the right to participate can be put into practice from theory.

The limitations of this study are as follows: the small size of the study group, the implementation of the action plan in a certain amount of time, and not taking the opinions of teachers and families apart from children. More comprehensive results can be obtained by extending the aim of the action plan used in this study, which addresses significant improvements in children's participation, at the teacher and family level, and by applying it over longer periods. At the same time, it is thought that the positive effects of the action plan will contribute to the social studies to be conducted regarding the right to participate.

\section{Conclusion and Recommendations}

Within the scope and purpose of this research, it was aimed to show how the action plan, including concrete and new arrangements to improve the children's participation, affected the improvement of children participation. The findings of the study clearly revealed that children began expressing their opinions on the planning of program activities and began taking an active role in decision-making process. It was observed that students started to gain awareness of their choices as active participants in the learning process at the school. The children reported that they liked the new arrangements and the materials they used.
In line with the action plan used within the scope of this research, activities can be prepared to raise awareness of young children about their right to participate in educational programs. Observational evaluation tools can be created by taking the opinions of teachers, administrators, and specialists in this field to evaluate the level of participation of children at school. Comprehensive action plans can be developed by experts working on children and education policymakers to implement children's participation right in school. In addition to the children's right to participate in school, education programs can be developed to improve children's right to participate in families, society, and health institutions.

\section{References}

Alderson, P. (2008). Young children's rights: Exploring beliefs, principles and practice. London: Jessica Kingsley Publishers.

Bae, B. (2009). Children's right to participate: Challenges in everyday interactions. European Early Childhood Education Research Journal, 17(3), 391-406. doi: 10.1080/13502930903101594

Berthelsen, D. (2009). Participatory learning: Issues for research and practice. In. Berthelsen, J. Brownlee and E. Johansson, (Eds.), Participatory learning in the early years: Research and pedagogy, (pp.1-11). London: Routledge.

Bowden-Clissold, N. (2013). A child-centred early years curriculum? How do we increase children's voices to realise this? (Unpublished Doctoral Dissertation), University of the West of England.

Büyüköztürk, S.., Kılıç Çakmak, E., Akgün, Ö. E., Karadeniz, Ş., \& Demirel, F. (2012). Bilimsel araştırma yöntemleri [Scientific research methods]. Ankara: Pegem Academy.

Church, A., \& Bateman, A. (2019). Childrens right to participate: How can teachers extend child-initiated learning sequences? International Journal of Early Childhood, 51, 265281. doi:10.1007/s13158019-00250-7

Clark, A. (2010). Transforming children's spaces: children's and adults' participation in designing learning environments. London: Routledge.

Clark, A., McQuail, S. \& Moss, P. (2003). Exploring the field of listening to and consulting with young children. Research Report 445. London: Department for Education and Skills. 
Clark, A., \& Moss, P. (2010). Listening to young children. The mosaic approach. London, UK: National Children's Bureau and Joseph Rowntree Foundation.

Clement, J. (2019). Spatially democratic pedagogy: children's design and co-creation of classroom space. International Journal of Early Childhood, 51, 373-387. doi: 10.1007/s13158-019-00253-4

Correia, N., \& Aguiar, C. (2017). Choosing classrooms: A structured interview on children's right to participate. International Journal of Educational Research, 82, 54-62. doi:10.1016/j.ijer.2017.01.004.

Donaldson, G. (2015). Successful futures: Independent review of curriculum and assessment arrangements in wales. Cardiff: Crown Copyright.

Emilson, A., \& Johansson, E. (2018). Values in Nordic early childhood education: Democracy and the child's perspective. In M. Fleer, \& B. van Oers (Eds.), International handbook of early childhood education (pp. 929-954). Dordrecht: Springer.

Gillis, A., \& Jackson, W. (2002). Research methods for nurses: Methods and interpretation. Philadelphia: F.A. Davis Company.

Hammersley, M. (2017). Childhood studies: A sustainable paradigm? Childhood, 24(1), 113-127. doi: 10.1177/0907568216631399

Hart, R. A (1992). Children's participation: From tokenism to citizenship. Retrieved from http://www. unicef.org/adolescence/cypguide/index concepts.html

Hendricks, C. (2006). Improving schools through action research: A comprehensive guide for educators. Boston: Pearson Education Publishers.

Hester, S., \& Moore, A. (2018). Understanding children's participation through an Eliasian lens: Habitus as a barrier to children's everyday participation rights. International Journal of Children's Rights, 26(3), 446-467. doi: 10.1163/15718182-02603002

Horgan, D. (2017). Child participatory research methods: Attempts to go deeper. Childhood, 24(2), 245-259. doi: 10.1177/0907568216647787

Houen, S., Danby, S., Farrell, A., \& Thorpe, K. (2016). 'I wonder what you know...' teachers designing requests for factual information. Teaching and Teacher Education, 59(1), 68-78. doi: 10.1016/j. tate.2016.02.002
Hudson, K. (2012). Practitioners' views on involving young children in decision making: Challenges for the children's rights agenda. Australasian Journal of Early Childhood, 37(2), 4-9. doi: 10.1177/183693911203700202

Johansson, E., Emilson, A., Röthle, M., Puroila, A.-M., Broström, S., \& Einarsdóttir, J. (2016). Individual and collective rights expressed in educator and child interactions in Nordic preschools. International Journal of Early Childhood, 48, 1-16. doi: 10.1007/s13158-016-0164-2

Johnson, A. P. (2015). Eylem araştırması el kitabı. (Çev. Edt. Y. Uzuner and M. Özten Anay) Ankara: Anı Publishing.

Joseph, D., Soon, A., Chang, R. H. L., \& Slaughter, S. A. (2010). Practical intelligence in IT: Assessing soft skills of IT professionals. Communications of ACM, 53(2), 149-154. doi: 10.1145/1646353.1646391

Kanyal, M. I., \& Cooper, L. (2012). Young children's perceptions of their classroom environment: perspectives from England and India. Cross cultural perspectives on early childhood. pp.5872. London: Sage.

Koran, N. (2017). Participation right in classrooms: The understanding of participation right of early childhood teachers' and supporting the understanding of participation right of early childhood teachers (Unpublished Doctoral Dissertation). Gazi University, Ankara, Turkey.

Koran, N., \& Avcı, N. (2017). Perceptions of prospective pre-school teachers regarding children's right to participate in classroom activities. Educational Sciences: Theory and Practice, 17(3), 1035-1059. doi: 10.12738/estp.2017.3.0325

Lansdown, G. (2005). Can you hear me? The right of young children to participate in decisions affecting them working paper in early childhood development No:36. The Hague: Bernard Van Leer Foundation.

Leinonen, J., \& Venninen, T. (2012). Designing learning experiences together withchildren. Procedia Social and Behavioral Sciences, 45(2012), 466474. doi: 10.1016/j.sbspro.2012.06.583

Lincoln Y., \& Guba, E. G. (1985). Naturalistic inquiry. Newbury Park, CA: Sage.

MacNaughton, G., \& Hughes, P. (2009). Doing action research in early childhood studies. A step by step guide. Berkshire: Open University Press. 
Miles, M. B., \& Huberman, A. M. (1994). Qualitative data analysis. Thousand Oaks,CA: Sage.

Ministry of National Education (2013). (MoNE) Preschool education program. Ankara: Ministry of National Education General Directorate of Basic Education.

Muela, A., Larrea, I., Miranda, N., \& Barandiaran, A. (2019). Improving the quality of preschool outdoor environments: Getting children involved. European Early Childhood Education Research Journal, 27(3), 385-396, doi: $10.1080 / 1350293 \times .2019 .1600808$

Nordtømme, S. (2012). Place, pace and materiality for pedagogy in a kindergarten. Education Inquiry, 3(3), 317-333. doi: 10.3402/edui.v3i3.22037

Nyland, B. (2009). The guiding principles of participation. Infant, toddler groups and the United Nations Convention on the Rights of the Child. In D. Berthelsen, J. Brownlee \& E. Johansson (Eds.), Participatory learning in the early years: Research and pedagogy (pp.164184). London: Routledge.

Ojala, M., \& Venninen, T. (2011). Developing reflective practices for day-care centers in the Helsinki Metropolitan area. Reflective Practice, 12(3), 335-346. doi: 10.1080/14623943.2011.571865

Puroila, A. M., Estola, E., \& Syrjälä, L. (2012). Having, loving, and being: Children's narrated well being in Finnish day care centres. Early Child Development and Care, 182(3-4), 345-362. doi: $10.1080 / 03004430.2011 .646726$

Ree, M., \& Emilson, A. (2019). Participation in communities in ECEC expressed in childeducator interactions. Early Child Development and Care, doi: 10.1080/03004430.2019.1566230

Salminen, E. J. (2013). Case study on teachers' contribution to children's participation in Finnish preschool classrooms during structured learning sessions. Frontline Learning Research, 1, (2013), 72-80.

Sargeant, J., \& Gillett-Swan, J. K. (2019). Voice-inclusive practice (VIP): A charter for authentic student engagement. International Journal of Children's Rights, 27(1), 122-139. doi: 10.1163/1571818202701002

Shier, H. (2001). Pathways to participation: Openings, opportunities and obligations. Children \& Society, 15, 107-117. doi:10.1002/chi.617
Smaree Manassakis, E. (2019). Children's participation in the organisation of a kindergarten classroom. Journal of Early Childhood Research, 1-11 doi:10.1177/1476718X19882714

Smith, K. (2015). Action research with children. In Olivia N. Saracho (Ed.), Handbook of research methods in early childhood education (pp 547576). Charlotte, NC: Information Age Publishing.

Struthers, A. E. C. (2015). Human rights education: Educating about, through and for human rights. The International Journal of Human Rights, 19(1), 53-73. doi: 10.1080/13642987.2014.986652

Şallı Idare, F. (2018). The investigation of children's and teachers views on child participation in preschool education environments (Unpublished Master's Thesis). Gazi University, Ankara, Turkey.

Taylor, C., Rhys, M., Waldron, S., Davies, R., Power, S., Maynard, T., et al. (2015). Evaluating the foundation phase: Final report. Cardiff: Welsh Government.

Thayer, S., \& Schiff, W. (1969). Stimulus factors in observer judgment of social interaction: Facial expression and motion pattern. The American Journal of Psychology, 82(1), 73-85. doi: 10.2307/1420608

Theobald, M., Danby, S., \& Ailwood, J. (2011). Child participation in the early years: Challenges for education. Australasian Journal of Early Childhood, 36(3), 19-26. doi: 10.1177/183693911103600304

Theobald, M. A., \& Kutti, A. (2012). Investigating child participation in the everyday talk of teacher and children in a preparatory year. Contemporary Issues in Early Childhood, 13(3), 210-225. doi: 10.2304/ciec.2012.13.3.210

Touhill, L. (2013). National quality standard professional learning program: Play based approaches to literacy and numeracy. Canberra, ACT, Australia: Early Childhood Australia.

United Nations Children's Fund. (1989). United nation convention of the rights of the child.

United Nations Committee on the Rights of the Child (2009). General comment no. 12: the right of the child to be heard. Available at: http:// www2.ohchr.org/english/bodies/crc/docs/ AdvanceVersions/CRC-C GC 12.pdf 
Venninen, T., \& Leinonen, J. (2013). Developing children's participation through research and reflective practices. Asia-Pacific Journal of Research in Early Childhood Education, 7(1), 31-49.

Venninen, T., Leinonen, J., Lipponen, L., \& Ojala, M. (2014). Supporting children's participation in Finnish child care centers. Early Childhood Education Journal, 42(3), 211-218. doi:10.1007/s10643-0130590-9

Venninen, T., Leinonen, J., Ojala, M., \& Lipponen, L. (2012). Creating conditions for reflective practice in early childhood education. International Journal of Child Care and Education Policy, 6, 1-15. doi: 10.1007/2288-6729-6-1-1

Wall K., Cassidy, C., \& Robinson, C, et al. (2019). "Look who's talking: Factors for considering the facilitation of very young children's voices. Journal of Early Childhood Research, 17(4), 263278. doi: 10.1177/1476718X19875767

Yıldırım, A., \& Şimşek, H. (2016). Nitel araştırma yöntemleri [Qualitative research methods]. Ankara: Seçkin Publishing.

Zorbay Varol, S. (2019). Investigation of children's the participation and situations affecting the participation in preschool education institutions (Unpublished Master's Thesis). Gazi University, Ankara, Turkey. 